\title{
Investigating Consumer Preferences in Choosing Vegetarian Restaurants Using Conjoint Analysis
}

\author{
Chia-Hsin Cheng ${ }^{1}$, Shih-Yen Lin ${ }^{2 *}$, Chia-Ching Tsai ${ }^{3}$ \\ ${ }^{1}$ Department of Accounting, National Yunlin University of Science and Technology, Yunlin City, Taiwan \\ ${ }^{2}$ Department of Hospitality Management, National Chi Nan University, Nanto City, Taiwan \\ ${ }^{3}$ Department of Business Administration, National Yunlin University of Science and Technology, Yunlin City, \\ Taiwan \\ Email: ${ }^{*}$ g9720801@yuntech.edu.tw
}

Received 27 July 2014; revised 25 August 2014; accepted 20 September 2014

Copyright (C) 2014 by authors and Scientific Research Publishing Inc.

This work is licensed under the Creative Commons Attribution International License (CC BY).

http://creativecommons.org/licenses/by/4.0/

(c) (i) Open Access

\begin{abstract}
People who eat out in urban are more common than ever before. However, restaurant foods are often high in calories, and lack for enough vegetables. Moreover, they provide too many calories from animal fat and protein resulting in a high risk of cardiovascular and other chronic diseases. Furthermore, a diet high in animal products contributes to global warming. For these reasons, a vegetarian diet can be recommended. The main purposes of this study are the following: (1) Understanding and evaluating the customers' preferences when selecting vegetarian restaurants. (2) In order to decrease the disease risks and the negative impact on the planet caused by a meat diet, researching ways to encourage consumers to choose vegetarian restaurants. The results of conjoint analysis indicated that when people choose vegetarian restaurants, they prefer ones that provide Chinese style cuisines, organic foods, cuisines that can help to lose weight, interiors with simple décor and ones that promote environmental protection.
\end{abstract}

\section{Keywords}

Vegetarian Restaurant, Consumer Preference, Chronic Diseases, Global Warming, Environmental Sustainability, Conjoint Analysis

\section{Introduction}

More and more people work and live in the urban in Taiwan for the convenience who choose eat out every day.

${ }^{*}$ Corresponding author. 
According to a survey of Unilever Global Company (2011), the proportion of people that eat out daily in Taiwan has reached $80 \%$ of the population; nearly 4.2 times eat in lunch and 3.3 times in dinner away from home per week. However, although eating out is convenient, it is also associated with lower nutritional quality and weight gain.

Increased consumption of away-from-home foods has been associated with the increased intake of calories, saturated fat, added sugars, and sodium, fewer fruits and vegetables, and less fiber, and vitamins (Kant \& Graubard, 2004; Schmidt et al., 2005). Furthermore, it is associated with excessive consumption of animal fat and protein, resulting in higher risk of the cardiovascular and chronic diseases. The Department of Health of Taiwan's data show that of the top ten causes of death, seven of them are caused by chronic diseases. Moreover, younger members of society are being diagnosed with these chronic diseases and experts believe it is related to poor diet and nutrition (Lai, 2005). The evidence in Europe show the importance of nutritional factors in preventing disability and death suggesting that $4.4 \%$ of the overall burden of disease in the region could be attributed to low vegetarian foods intake (WHO, 2003). Thus, consumption of vegetarian diets such as fruits and vegetables is important for human health because these foods are primary sources of some essential nutrients and contain phytochemicals that may lower the risk of chronic disease (Stahler, 2009). Eating these foods not only can provide rich and high quality vegetable protein and dietary fiber but also can promote intestinal health.

However, in addition to health factors for eating more vegetarian foods, according to Livestock's Long Shadow, the widely-cited 2006 report by the Food and Agriculture Organization of the United Nations (FAO), it estimates that the livestock industry generates 18 percent of annual worldwide GHGs emissions, more than cars and planes GHGs emissions, and these carbon emissions cause serious harm to the climate (Goodland \& Anhang, 2009).

Thus, in order to protect the environment, eating more vegetarian diets are actually a responsibility of all people. According the Vegetarian Publication reported that the north city of Belgium, Ghent, has set every Thursday as "Vegetarian Day". This policy began in 2009 and today Ghent is the world's foremost green city. Santiago City of Philippines also passed a similar vegetarian resolution and set every Friday as vegetarian day in the same year (Lai, 2010). From the above, governments are attempting to implement green city plans and to promote vegetarian lifestyles. Eating a more vegetarian diet in addition to enhancing human health is also environmentally friendly.

Conjoint analysis is a very powerful tool for obtaining information about the effect of different product attributes on liking and/or purchase intent of food products (Green \& Srinivasan, 1978), and there is little research using conjoint analysis to study consumer behavior on their choices of restaurants. Hence, the main purposes of this study are the following: (1) Understanding and evaluating the customers' preferences when selecting a vegetarian restaurant. (2) In order to decrease the disease risks and the negative impact on the planet caused by a meat diet, researching ways to encourage consumers to choose vegetarian restaurants.

\section{Literature Review}

\subsection{The Importance of Vegetarian Diets}

The WHO (2003) has defined health as "not only the absence of a disease or infirmity, but a complete state of physical, mental and social well-being". The recent data indicate that vegetarian diets are important sources of a wide range of vital micronutrients, and there is evidence strongly indicating vegetarian consumption can effectively prevent a number of chronic diseases including cardiovascular disease and some cancers (IARC, 2003; Robertson et al., 2004). Because vegetarian diets contain diverse quantities of antioxidant secondary metabolites that play an important role as health-protective factors, they can neutralize the dangerous effect of free radicals in our cells. Thus, increasing the consumption of vegetarian diets can not only result in the prevention of chronic diseases (Blasa et al., 2010) but also be a very cost-effective method for health promoting (Gundgaard et al., 2003).

On the other hand, according to the Intergovernmental Panel on Climate Change's (IPCC) assessment report "climate change is a result of global warming, and that change is man-made" (Lai, 2010). Goodland and Anhang (2009) indicated the following: "We believe that the supply chain of domesticated animals raised for food have been vastly underestimated as a source of GHGs, the livestock and their byproducts actually account for at least 32,564 million tons of $\mathrm{CO}_{2}$ per year, or 51 percent of annual worldwide GHGs emissions. More than $50 \%$ of global greenhouse gases come from livestock, and more than $80 \%$ of the Amazon rainforest has been cut down 
to produce meat, however, the rainforest serves as the lung of the earth and produces oxygen and absorbs carbon dioxide". Moreover, the FAO also pointed out that the phenomenon of over-fishing has led to important fishing grounds in the world being lost. Over-fishing has resulted in the failure of $70 \%$ of the most important fish populations (U. N. Report, 2010).

The above-mentioned of U. N. Report claims that a "Vegetarian diet was better for the planet and lesser consumption of animal products is necessary to save the world from the worst impacts of climate change". Therefore, to eat less meat not only can reduce the scale of livestock, but is can also reduce greenhouse gas emissions (Washington, D.C., 2009).

\subsection{The Definition and Effects of Product Attributes}

Products are items that are valuable for exchange in the process of exchange, and can be exchanged in the market. They can be physical objects or intangible services (Lin, 2002). Each product is made of a combination of many different product attributes, consumers compare competing brands of products and their final choice is based on those product attributes (Cao, 2001). In a word, product attributes are the characteristics of a product. Recently, the population of people eating out is increasingly growing. Consumers are more aware of and care more about nutrition. In the Knutson and Patton (1993) study, they found the mature consumers are increasingly concerned about eating and how it may affect their health and longevity. The WHO (2003) also stated that the impact of vegetarian diets on human health is very helpful. A study of consumers about restaurants' menus found that $21 \%$ of respondents thought health and nutrition noted on the menus as important (Glanz et al., 2007). Thus, promoting a healthier diet could be one successful future strategy used by the restaurant industry.

In addition to health reasons, customers typically choose a product or service of a restaurant which consists of multi-attributes (Lewis et al., 1991). Such as food quality, convenience of location; cleanliness; price (Almanza et al., 1994; Knutson \& Patton, 1993); hygienic and comfortable environment (Soriano, 2002); restaurant design and layout (Ryu \& Jang, 2008); taste and nutritional (Lee \& Crange, 2007), moreover, Hu et al. (2010) suggested that green food and green practices of restaurant operations are important factors for consumers when selecting a restaurant. Restaurants that use green products can strengthen their eco-friendly image to attract more customers' attention and enhance customer satisfaction as reported by Manaktola and Jauhari (2007).

Base on above literature mentioned, we conclude that the most important attributes to attract customers include the following: food quality, taste, reasonable price, nutritional aspects, restaurant appearance, less meat can help reduce global warming, clean dining environment, excellent service, well-designed physical facilities, convenient location, and healthy food on the menu. There are many attributes and factors that can influence consumers to choose a restaurant. Restaurant owners can improve their chances of success by being aware of the most important attributes, than planning a healthy menu.

\subsection{Conjoint Analysis}

The tool chosen for this research is conjoint analysis (CA). In conjoint analysis (CA), the characteristics of a product are described in terms of "attributes". Variations within an attribute are described as "levels". Attribute levels are the values of the independent variables (Reddy et al., 1995). Hence, CA is a multi-variate technique, which determines the relative importance of a product's multi-dimensional attributes and measures the consumers' degree of preferences for each level of each attribute (Green \& Srinivasan, 1978). CA allows product attributes to be considered jointly rather than in isolation. Besides, CA can establish the relative importance of different attributes in the provision of a good or a service and also be used to estimate how individuals trade between these attributes (Ryan, 1999). The relative importance of each attribute is calculated as the utility range. CA can better predict the overall consumer preference by aggregating the utility scores of each product attribute. In order to analyze the preference between levels within each attribute, the partial utilities or part-worth have been used, the preferences to determine the value of each attribute (Green \& Krieger, 1996). For each level of each attribute, large part-worth values are assigned to the most preferred levels, and small part-worth values are assigned to the least preferred levels. The part worth estimates can serve as a basis for predicting the choice probabilities of various combinations of attribute levels (Myung, 2003).

Usually, a fractional factorial design is used, and uses the orthogonal array in experimental design, which assumes away most interactions among the independent variables considering only main effects (Lewis et al., 1991). The attributes may be related directly to the sensory properties of the product or service provided by the 
experimenter. For each of the factor combination, each consumer is asked to give his/her liking or purchase intent score (Nñs et al., 2001).

\section{Research Method}

\subsection{Procedure}

There are predominantly four stages in the design of a CA study as described by Lehmann et al. (1998), and Van der Pol and Ryan (1996), the design of each of the stages as applicable for our study is discussed below.

\subsubsection{Establishing the Attributes to Be Tested}

The first stage in the design of a CA study is to establish the attributes to be included in the study. It was recognized that many attributes will have potential influence on an individual's choosing vegetarian restaurants. Based on the above literature mentioned and on interviews with owners of vegetarian restaurants who choose the 8 most important items of vegetarian restaurants preliminary attributes and designed the questionnaires, then, we used the convenience sampling to survey 50 respondents who were eating in the vegetarian restaurants in Taichung from December 3 to December 13, 2013. We request that those respondents choose the 5 most important attributes by ranking those items when searching for a vegetarian restaurant. Order 1 means the most important attribute and order 5 is the least important attribute. Using the data collected from those questionnaires, we used reverse scoring: order 1 is given a score of 5 , and order 5 is given a score of 1 . Next, we calculated all the scores of attributes, and then summed up the 5 most important attributes which are shown on Table 1 . They include the following five attributes: 1) food quality, 2) cuisine style, 3) health concept, 4) restaurant design, and 5) environmental protection. These five attributes were the top five most important ones when selecting vegetarian restaurants.

\subsubsection{Assigning Levels to the Attributes}

Based on the steps of CA analysis which were proposed by Green and Srinivasan (1978), our study chose two or three levels for each attribute (see Table 2). Levels chosen for each attribute must be defined in a way that is meaningful to respondents in order to ensure the attributes are measured objectively and are able to be controlled (Centre for International Economics, 2001). In this stage, the attribute levels to be used in the experiment were set using both the previous questionnaires information and exploratory interviews carried out with managers who were well acquainted with the area (expert judgment method and group interviews). Then, the five typography design attributes and their corresponding levels were defined, as shown in Table 2.

\subsubsection{Establishing Which Scenarios to Present Respondents}

There are $48\left(3^{1} \times 2^{4}\right)$ possible profiles (all the possible attribute combinations) to be presented for each use. A very large number of possible vegetarian restaurant attributes would be generated. Presenting many profiles to respondents would result in respondent fatigue and poor results. In order to reduce this complexity and the asso-

Table 1. Results of attributes for customers selecting vegetarian restaurants.

\begin{tabular}{cc}
\hline Attributes & Total Scores \\
Food quality & 153 \\
Cuisine style & 139 \\
Health concept & 137 \\
Restaurant design & 91 \\
Environmental protection & 84 \\
Price & 73 \\
Diversity of menu & 63 \\
Professional service & 17 \\
\hline
\end{tabular}


ciated negative impacts, our study used the orthogonal fractional factorial design (Phadke, 1989) reduce the relative important profiles presented to 8 while still allowing for the main effects to be estimated without confounding results. The total number of final stimuli description of the 8 profiles is shown in Table 3.

\subsubsection{Establish Preferences}

The 8 stimuli are the vegetarian restaurants portfolio to interview respondents, and we used the full profile to present the stimuli data. That means each set of attributes and the level of the portfolio of products with the letter detailed description to design the questionnaire and complete presented to respondents, and investigate the preference of stimuli. Respondents were asked to read the letter description than rate their preference for each scenario from 1 to $8(1=$ most preferred, $8=$ least preferred $)$. A carefully constructed introduction preceded the CA section of the interview to allow the respondents to clearly understand the context of the study.

\subsubsection{Conjoint Analysis of Pilot Study}

In order to confirm the validity of the content of the 8 stimuli of the product portfolio, a pilot study of 50 senior students from the Department of Hospitality Management was undertaken on February 21, 2014 in I-Shou University in Kaohsiung. At this stage, participants were asked whether the items were appropriate for the questionnaires. A total of 50 pilot questionnaires were collected, six questionnaires were incomplete, and thus, the final sample size for the pilot statistical analysis was 44 . Pearson's R was .860 and Kendall's tau $=.786$ in the

Table 2. Attributes and attribute levels.

\begin{tabular}{lc}
\hline Typography Design Attributes & Attribute Level in the Research Design \\
\hline 1.Food quality & (1) Organic food \\
& (2) Colorful food \\
2.Cuisine style & (3) Nutritious food \\
3.Health concept & (1) Chinese style \\
4.Restaurant design & (2) Italian style \\
& (1) Lose weight \\
5.Environmental protection & (2) Prevent diseases \\
& (1) Simple design \\
& (2) Fashion design \\
\hline
\end{tabular}

Table 3. Stimuli profile of vegetarian restaurants.

\begin{tabular}{|c|c|c|c|c|c|}
\hline $\begin{array}{l}\text { Stimuli } \\
\text { Profile }\end{array}$ & Food Quality & $\begin{array}{c}\text { Cuisine } \\
\text { Style }\end{array}$ & $\begin{array}{c}\text { Health } \\
\text { Concept }\end{array}$ & $\begin{array}{c}\text { Restaurant } \\
\text { Design }\end{array}$ & $\begin{array}{c}\text { Environmental } \\
\text { Protection }\end{array}$ \\
\hline 1 & Organic & Chinese & Lose weight & Simple & Care \\
\hline 2 & Organic & Italian & Prevent diseases & Fashion & Doesn't care \\
\hline 3 & Organic & Chinese & Prevent diseases & Fashion & Care \\
\hline 4 & Nutritious & Chinese & Lose weight & Fashion & Doesn't care \\
\hline 5 & Colorful & Italian & Lose weight & Fashion & Care \\
\hline 6 & Colorful & Chinese & Prevent diseases & Simple & Doesn't care \\
\hline 7 & Organic & Italian & Lose weight & Simple & Doesn't care \\
\hline 8 & Nutritious & Chinese & Prevent diseases & Simple & care \\
\hline
\end{tabular}


pilot study which indicates that the overall fit of the model and has good predictability for the product preference of choosing vegetarian restaurants.

\subsection{Survey Instrument}

The questionnaire used in this study consisted of three major parts. The first part of the questionnaire comprises 5 items to assess willingness, motivation, consideration, attractiveness and budget when selecting vegetarian restaurants. The second part of the questionnaire is comprised of 8 stimuli of the product portfolio with the letter detailed description of vegetarian restaurants to assess preference ranking: ranking 1 means the first preferred level and ranking 8 means the lowest preferred level. The third part of the questionnaire consists of 7 items to investigate the background information of respondents including sex, age, occupation, education, religious belief, and income.

An on-site survey using self-administered questionnaires was adopted as the method of data collection. It was done at MRT station in Taipei, Taichung and Kaohsiung, from March 10 to April 15, 2014. Our study used random sampling to recruit one of every five customers when they passed by the interviewers. A total of 250 questionnaires were collected; however, 31 questionnaires were incomplete, which resulted in their deletion. The final sample size for statistical analysis was 219 . The response rate was $87.6 \%$.

\section{Results}

\subsection{Participants}

Table 4 summarizes the demographic profile of the respondents. Respondents consisted of $39.3 \%$ male participants and $60.7 \%$ female participants. Nearly three quarters (74\%) of respondents were between the ages of 20 to 40, having an educational level of Bachelor degree (66.2\%). Approximately $32.9 \%$ of respondents are engaged in service industry, and $30.5 \%$ of respondents had monthly incomes between NT\$25,001 to NT\$ 40,000. The majority of respondents were none religious belief (35.6\%). 32.0\% of respondents lived in Taipei.

\subsection{The Results of Consumer Preference for Selecting Vegetarian Restaurants}

Table 5 summarizes the motivation for selecting vegetarian restaurants, the main motivation was "for health" (42.5\%), the second motivation was "prefer natural food" (28.8\%) and the third motivation was "reducing global warming" (10.0\%). Table 6 indicates the first consideration to go to the vegetarian restaurants was "for health" (32.9\%) and the second consideration was "food type" (31.5\%); as regards the main attractiveness of consuming in a vegetarian restaurant, "for health" (29.2\%) again ranked first and "food taste" (25.6\%) ranked second. Most of the respondents (42.9\%) were willing to pay NT\$150 - NT\$280 for a vegetarian meal, and 33.3\% of respondents were willing to pay NT\$281 to NT\$400 (See Table 7).

\subsection{Results of Conjoint Analysis}

Conjoint analysis was used to analyze the preference of product attributes for consumers who choose vegetarian restaurants including food quality, cuisine style, health concept, restaurant design and environmental protection. Respondents were asked to rate their preference for each scenario from 1 to 8 ( 1 = most preferred, 8 = least preferred).

Table 8 shows that the relative importance values and the favorite attribute levels of the consumers selecting vegetarian restaurants. We found that Pearson's R was .820 and Kendall's tau was .771 which indicated that the overall fit of the model was good. The results confirm that conjoint analysis has good predictability for consumers choosing vegetarian restaurants. "Food quality" is the most preferred factor with a relative importance value of $34.62 \%$ in selecting vegetarian restaurants, followed by "environmental protection "(17.27\%). As the food quality aspect, consumers prefer the vegetarian restaurants which provide "organic food" (.344); as the cuisine style aspect, consumers prefer "Chinese style"(.064); about the health concept aspect, consumers prefer "lose weight" (.048); related to restaurant design, respondents prefer a "simple design"(.023), with regard to the environmental protection aspect, respondents prefer vegetarian restaurant owners whose mission of operation is to “care” about environmental protection and sustainability (.233). 
Table 4. Demographics of respondents.

\begin{tabular}{|c|c|c|c|c|c|}
\hline Characteristics & $\mathrm{N}$ & \% (219) & Characteristics & $\mathrm{N}$ & $\%(219)$ \\
\hline Willing & & & Monthly Income (NT\$) & & \\
\hline Yes & 205 & 93.6 & Under 10,000 & 50 & 22.8 \\
\hline No & 14 & 0.6 & $10,000-25,000$ & 34 & 16.0 \\
\hline Gender & & & $25,001-40,000$ & 67 & 30.5 \\
\hline Male & 86 & 39.3 & $40,001-55,000$ & 34 & 15.6 \\
\hline Female & 133 & 60.7 & $55,000-70,000$ & 16 & 7.3 \\
\hline Age & & & More than 70,001 & 17 & 7.8 \\
\hline 20 or younger & 9 & 4.1 & Religious Belief & & \\
\hline $21-30$ & 105 & 47.9 & Buddhism & 61 & 27.9 \\
\hline $31-40$ & 57 & 26.0 & Taoism & 62 & 28.3 \\
\hline $41-50$ & 39 & 17.8 & Christianity & 6 & 2.7 \\
\hline 51 or older & 9 & 4.1 & Catholicism & 2 & 0.9 \\
\hline Education & & & None & 78 & 35.6 \\
\hline Junior & 3 & 1.4 & Other & 10 & 4.6 \\
\hline Senior & 13 & 5.9 & Location & & \\
\hline Bachelor & 145 & 66.2 & Taipei & 70 & 32.0 \\
\hline Master or above & 58 & 26.5 & North of Miaoli & 20 & 9.1 \\
\hline Occupation & & & Taichung & 39 & 17.8 \\
\hline Students & 58 & 26.5 & Yulin \&Jiayi & 21 & 9.6 \\
\hline Service & 72 & 32.9 & Kaohsiung & 32 & 14.6 \\
\hline Manufacturing & 16 & 7.3 & Pingtung & 32 & 14.6 \\
\hline Science & 5 & 2.3 & East of Taiwan & 1 & 0.5 \\
\hline Finance & 13 & 5.9 & Other & 4 & 1.8 \\
\hline Teaching & 28 & 12.8 & & & \\
\hline Free & 7 & 3.2 & & & \\
\hline Unemployed & 6 & 2.7 & & & \\
\hline Other & 14 & 6.4 & & & \\
\hline
\end{tabular}

Table 5. Motivation of participants of choosing vegetarian restaurants.

\begin{tabular}{ccc}
\hline Characteristics & N & \% (219) \\
Motivation & & 42.5 \\
For health & 93 & 28.8 \\
Prefer natural food & 63 & 10.0 \\
Reducing global warming & 22 & 9.1 \\
Other & 20 & 5.0 \\
Religious belief & 11 & 4.6 \\
Vogue & 10 & \\
\hline
\end{tabular}


Table 6. Consideration and Attractiveness for choosing vegetarian restaurants.

\begin{tabular}{cll}
\hline Consideration & N & \% (219) \\
\hline For health & 72 & 32.9 \\
Food type & 69 & 31.5 \\
Food taste & 42 & 19.2 \\
Décor \& atmosphere & 13 & 5.9 \\
Reducing global warming & 12 & 5.5 \\
Green restaurant & 9 & 4.1 \\
Other & 2 & 0.9 \\
Attractiveness & & 29.2 \\
For health & 64 & 25.6 \\
Food taste & 56 & 23.7 \\
Food type & 52 & 10.0 \\
Décor \& atmosphere & 22 & 5.0 \\
Green restaurant & 11 & 3.7 \\
Reducing global warming & 8 & 2.7 \\
Other & 6 & \\
\hline
\end{tabular}

Table 7. Budget of participants for choosing vegetarian restaurants.

\begin{tabular}{|c|c|c|}
\hline Characteristics & $\mathrm{N}$ & $\%(219)$ \\
\hline \multicolumn{3}{|l|}{ Willing to Pay } \\
\hline Under NT \$150 & 28 & 12.8 \\
\hline NT \$151 NT \$280 & 94 & 42.9 \\
\hline NT \$281 NT \$400 & 73 & 33.3 \\
\hline NT \$401 NT \$500 & 20 & 9.1 \\
\hline More than NT \$551 & 4 & 1.8 \\
\hline
\end{tabular}

\section{Discussion}

This study investigated the preferences of customers selecting vegetarian restaurants. The results indicate that 93.6\% of consumers are willing to dine at vegetarian restaurants, and most consumers who choose a vegetarian restaurant are females. The main ages for those choosing vegetarian restaurants are adults between 21 to 40 (See Table 4). This result is similar to Perry's (2001) study which found that younger females (under 35) that chose vegetarian restaurant and their primary reason were concern about weight. They believed they could lose or control weight by eating a vegetarian diet as compared to a non-vegetarian one.

From the results of conjoint analysis indicated "food quality" can be the contributing factor when consumers choose vegetarian restaurants. These results are consistent with the findings of previous studies (Auty, 1992; Knutson \& Patton, 1993; Almanza et al., 1994; Sun, 1995; Soriano, 2002; Lo \& Lam, 2004; Sulek \& Hensley, 2004), which disclosed that food and beverage quality is the most important factor during the restaurants selection process, because people believe that dining pleasure and satisfaction comes from high quality food and beverages (Turner \& Collison, 1988). The investigation shows that "organic food" is the most important factor for customers when assessing food quality, because most consumers not only thought that organic food was considered healthier than conventional food (Grankvist \& Biel, 2001; Makatouni, 2002; Zanoli \& Naspetti, 2002; 
Table 8. Aggregate-level results of conjoint analysis.

\begin{tabular}{|c|c|c|c|}
\hline Typography Design Parameters & $\begin{array}{c}\text { Attribute } \\
\text { Utility }\end{array}$ & $\begin{array}{l}\text { Relative } \\
\text { Importance }\end{array}$ & Preference \\
\hline Food Quality & & $34.62 \%$ & \\
\hline (1) Organic food & .344 & & $\mathrm{~V}$ \\
\hline (2) Colorful food & -.215 & & \\
\hline (3) Nutritious food & -.129 & & \\
\hline Cuisine Style & & $16.85 \%$ & \\
\hline (1) Chinese style & .064 & & $\mathrm{~V}$ \\
\hline (2) Italian style & -.064 & & \\
\hline Health Concept & & $15.30 \%$ & \\
\hline (1) Lose weight & .048 & & $\mathrm{~V}$ \\
\hline (2) Prevent disease & -.048 & & \\
\hline Restaurant Design & & $15.95 \%$ & \\
\hline (1) Simple design & .023 & & $\mathrm{~V}$ \\
\hline (2) Fashion design & -.023 & & \\
\hline Environmental Protection & & $17.27 \%$ & \\
\hline (1) Care & .233 & & $\mathrm{~V}$ \\
\hline (2) Doesn't Care & -.233 & & \\
\hline
\end{tabular}

Pearson’s R $=.820$ Sig. $=.0063$. Kendall's tau $=.771$ Sig. $=.0239$.

Radman, 2005), but felt that was much more beneficial to eat food grown without chemical additives, and the taste of organic food was considered by some to be superior to that of conventional food (Lockie et al., 2002; McEachern \& McClean, 2002; Radman, 2005). On the other hand, they think organic food is associated with health and social concerns as well as economic and environmental sustainability (Poulstona \& Yiua, 2011).

This study investigated the second most relatively important factor for selecting vegetarian restaurants which was “environmental protection”. The results were compatible with previous studies (Manaktola \& Jauhari, 2007; Hu et al., 2010) which indicated that the green restaurant are an important factor for consumers when selecting a restaurant. Because consumers believe that green products/practices are beneficial to the environment (Kalof et al., 1999) including eating less meat can get result in energy savings and carbon reduction, therefore, when firms use green products/practices, these products/practices not only enhance the product or company's eco-friendly image, but also enhance customer satisfaction. Such customers are willing to pay more for environmentally friendly products/services (Manaktola \& Jauhari, 2007; Vieregge et al., 2007).

"Cuisine style" was the third ranked relatively important factor of the conjoint analysis when consumers were selecting vegetarian restaurants. The finding is consistent with Koo et al. (1999), Liu and Jang (2009) who reported the style of cuisine is the important attribute when selecting a restaurant. Most of these consumers preferred "Chinese style” cuisine. In general, people prefer their own native flavors, owing to "Chinese food and beverage culture” it has been developed for more than 5000 years. And Chinese cuisine is prepared over vast areas with great regional diversity. Therefore, "Chinese style" cuisine is the preferred taste for consumers in our study. The study shows that restaurant design is the fourth relative factor when selecting vegetarian restaurants. More and more consumers believe that when restaurants make efforts on designs, layouts, exterior and interior decorations, these efforts will enhance their pleasure and satisfaction of the dining experience (Ryu \& Jang, 2008). Most consumers in our sample preferred a "simple design". That finding appears to be consistent with previous studies (Brady \& Cronin, 2001; Raajpoot, 2002). This finding shows that a simple but comfortable environment atmosphere will not only enhance the pleasure and satisfaction of the dining experience but also will play a specific role in customer decision making. 
The "health concept" ranked as the fifth most important factor when selecting vegetarian restaurants. Consumers preferred the "lose weight" concept and the findings are consistent with the study of Knutson and Patton (1993) that found that many mature consumers are increasingly concerned about health diet can help to lose weight. Most people are aware that they need to increase their fiber intake, fruits and more vegetarian foods in their diet to help them decrease chronic diseases (Wasserman \& Stahler, 1998) and promote their health.

\section{Conclusions}

The findings of this study indicate that Taiwanese who choose vegetarian restaurants prefer to lose weight, high food quality and food that is organic. They also prefer Chinese style cuisine especially cuisine method can help to lose weight, and restaurants that offer a simple design atmosphere, as well as these restaurants care about environmental protection. The most important motivator and main consideration as well as attractiveness were "for health", and thought that the "food quality" is the relatively important factor of other vegetarian restaurants attributes. The U.S. National Cancer Institute has initiated the " 5 A Day for Better Health" plan to encourage adults to consume at least 5 servings of $F$ \& Vs daily (CDC, 2007). In March 2007, the "5 A Day" goal was replaced with 7 - 13 (3 1/2 - 6 1/2 cups) servings F\&Vs daily (USDHHS, 2010). Owing to lifestyle changes, more and more people are concerned with health and longevity. Hence, they recognize that good food and nutrition can improve health and disease prevention, and in general, vegetarian foods have higher amounts of fiber, vitamins E, A, and C, thiamin, riboflavin, calcium, magnesium, iron, and potassium, and those ingredients not only prevent chronic diseases, such as obesity, hypertension, coronary disease, breast and colon cancer, but also are good for losing weight. In Wasserman and Stahler' findings (1998), they reported that 82\% of a sample of adults in the United States chose to eat a vegetarian diet for health reasons.

Moreover, for ethical and environmental reasons, eating a vegetarian diet has been shown to contribute to "ecosystem health" by reducing the impact on the environment and economies of pollution, and land degradation by grazing (Fox, 1999). A vegetarian diet saves water, has a smaller impact on global warming, decreases deforestation, is more humane with regards to animals, and protects the soil. Global warming is now recognized as a serious problem. Research has shown that a vegetarian diet is environmentally friendly and one way global citizens can actively be responsible for improving the situation.

Conjoint analysis is frequently used by marketers to understand consumer attitudes about a product with new attributes or features. A better understanding of people's reasons for choosing vegetarian restaurants would help vegetarian restaurant owners to design the most preferred product by customers and for planning products as well as make better decisions including providing nutritious menus, designing marketing strategies to promote their menus. These steps might encourage more people to dine frequently at vegetarian restaurants. Simultaneously, we hope the results of this study were expected to playing an important role in solving some of the world's most challenging environmental problems.

\section{References}

Almanza, B. A., Jaffe, W., \& Lin, L. (1994). Use of the Service Attribute Matrix to Measure Consumer Satisfaction. Journal of Hospitality \& Tourism Research, 17, 63-75. http://dx.doi.org/10.1177/109634809401700207

Auty, S. (1992). Consumer Choice and Segmentation in the Restaurant Industry. The Service Industries Journal, 12, 324-339. http://dx.doi.org/10.1080/02642069200000042

Blasa, M., Gennari, L., Angelino, D., \& Ninfali, P. (2010). Fruit and Vegetable Antioxidants in Health. In Bioactive Foods in Promoting Health: Fruits and Vegetables (pp. 37-58). San Diego, CA: Academic Press.

Brady, M. K., \& Cronin, J. J. (2001). Some New Thoughts on Conceptualizing Perceived Service Quality: A Hierarchical Approach. Journal of Marketing, 65, 34-49. http://dx.doi.org/10.1509/jmkg.65.3.34.18334

Cao, S. X. (2001). Tourism Marketing. Taipei: Yang-Chih Book Co., Ltd.

Centers for Disease Control and Prevention (CDC) (2007). Fruit and Vegetable Consumption among Adults, United States, 2005 (pp. 213-217). Morbidity and Mortality Weekly Report.

Centre for International Economics. (2001). Review of willingness-to-pay methodologies. Prepared for the Independent Pricing and Regulatory Tribunal of NSW, Canberra.

Fox, A. M. (1999). The Contribution of Vegetarianism to Ecosystem Health. Ecosystem Health, 5, 70-74. http://dx.doi.org/10.1046/j.1526-0992.1999.09911.x

Glanz, K., Resnicow, K., Seymour, J., Hoy, K., Stewart, H., L. M., \& Goldberg, J. (2007). How Major Restaurant Chains 
Plan Their Menus: The Role of Profit, Demand, and Health. American Journal of Preventive Medicine, 32, 383-388. http://dx.doi.org/10.1016/j.amepre.2007.01.003

Goodland, R., \& Anhang, J. (2009). Livestock and Climate Change. http://www.worldwatch.org/ww.livestock

Grankvist, G., \& Biel, A. (2001). The Importance of Beliefs and Purchase Criteria in the Choice of Eco-Labeled Food Products. Journal of Environmental Psychology, 21, 405-410. http://dx.doi.org/10.1006/jevp.2001.0234

Green, P. E., \& Krieger, A.M. (1996). Individualized Hybrid Models for Conjoint Analysis. Management Science, 42, 850867. http://dx.doi.org/10.1287/mnsc.42.6.850

Green, P. E., \& Srinivasan, V. (1978). Conjoint Analysis in Consumer Research: Issues and Outlook. Journal of Consumer Research, 5, 103-123. http://www.jstor.org/stable/2489001 http://dx.doi.org/10.1086/208721

Gundgaard, J., Nielsen, J. N., Olsen, J., \& Sørensen, J. (2003). Increased Intake of Fruit and Vegetables: Estimation of Impact in Terms of Life Expectancy and Healthcare Costs. Public Health Nutrition, 6, 25-30. http://dx.doi.org/10.1079/PHN2002355

Hu, H. H., Parsa, H. G., \& Self, J. (2010). The Dynamics of Green Restaurant Patronage. Cornell Hospitality Quarterly, 51, 344-362. http://dx.doi.org/10.1177/1938965510370564

IARC (2003). Fruit and Vegetables Protective Overall against Cancer. International Agency for Research on Cancer, Lyon. http://www.iarc.fr/en/media-centre/pr/2003/pr144.html

Kalof, L., Dietz, T., Stern, P. C., \& Guagnano, G. A. (1999). Social Psychological and Structural Influences on Vegetarian Beliefs. Rural Sociology, 64, 500-511. http://dx.doi.org/10.1111/j.1549-0831.1999.tb00364.x

Kant, A. K., \& Graubard, B. I. (2004). Eating out in America, 1987-2000: Trends and Nutritional Correlates. Preventive Medicine, 38, 243-249. http://dx.doi.org/10.1016/j.ypmed.2003.10.004

Knutson, B. J., \& Patton, M. E. (1993). Restaurants Can Find Gold among Silver Hair. Journal of Hospitality and Leisure Marketing, 1, 79-90. http://dx.doi.org/10.1300/J150v01n03_07

Koo, L. C., Tao, K. C., \& Yeung, J. H. C. (1999). Preferential Segmentation of Restaurant Attributes through Conjoint Analysis. International Journal of Contemporary Hospitality Management, 11, 242-253. http://dx.doi.org/10.1108/09596119910272784

Lai, C. Y. (2005). The Effects of College Students’ Health Diets Behaviors. Master's Thesis, Taipei: National Taiwan Normal University.

Lai, J. Y. (2010). Reduce Carbon and Eat Less Meat to Save the Earth. Vegetarian Publication.

Lee, S. J., \& Crange, D. A. (2007). The Relative Importance of Menu Attributes at Point of Menu Selection through Conjoint Analysis: Focused on Adolescents. Journal of Foodservice Business Research, 10, 3-18. http://dx.doi.org/10.1300/J369v10n02 02

Lehmann, D. R., Gupta, S., \& Steckel, J. H. (1998). Marketing Research. Boston, MA: Addison Wesley.

Lewis, R. C., Ding, S., \& Geschke, U. (1991). Using Trade-Off Analysis to Measure Consumer Choices: The Full Profile Method. Journal of Hospitality \&Tourism Research Journal, 15, 75-92. http://dx.doi.org/10.1177/109634809101500107

Lin, J. H. (2002). Marketing Management. Taipei: Best Wise Co., Ltd.

Liu, Y., \& Jang, S. (2009). Perceptions of Chinese Restaurants in the U.S.: What Affects Customer Satisfaction and Behavioral Intentions? International Journal of Hospitality Management, 28, 338-348. http://dx.doi.org/10.1016/j.ijhm.2008.10.008

Lo, A., \& Lam, T. (2004). Long-Haul and Short-Haul Outbound All-Inclusive Package Tours. Asia Pacific Journal of Tourism Research, 9, 161-176. http://dx.doi.org/10.1080/1094166042000233694

Lockie, S., Lyons, K., Lawrence, G., \& Mummery, K. (2002). Eating “Green”: Motivations behind Organic Food Consumption in Australia. Sociologia Ruralis, 42, 23-40. http://dx.doi.org/10.1111/1467-9523.00200

Makatouni, A. (2002). What Motivates Consumers to Buy Organic Food in the UK? Results from a Qualitative Study. British Food Journal, 104, 345-352. http://dx.doi.org/10.1108/00070700210425769

Manaktola, K., \& Jauhari, V. (2007). Exploring Consumer Attitude and Behavior towards Green Practices in the Lodging Industry in India. International Journal of Contemporary Hospitality Management, 19, 364-377.

http://dx.doi.org/10.1108/09596110710757534

McEachern, M.G., \& McClean, P. (2002). Organic Purchasing Motivations and Attitudes: Are They Ethical? International Journal of Consumer Studies, 26, 85-92. http://dx.doi.org/10.1046/j.1470-6431.2002.00199.x

Myung, R. (2003). Conjoint Analysis as a New Methodology for Korean Typography Guideline in Web Environment. International Journal of Industrial Ergonomics, 32, 341-348. http://dx.doi.org/10.1016/S0169-8141(03)00074-X

Nñs, T., Kubberød, E., \& Sivertsen, H. (2001). Identifying and Interpreting Market Segments Using Conjoint Analysis. Food 
Quality and Preference, 12, 133-143. http://dx.doi.org/10.1016/S0950-3293(00)00039-2

Perry, C. L., Mcguire, M. T., Neumark-Sztainer, D., \& Story, M. (2001). Characteristics of Vegetarian Adolescents in a Multiethnic Urban Population. Journal of Adolescent Health, 29, 406-416. http://dx.doi.org/10.1016/S1054-139X(01)00258-0

Phadke, M. S. (1989). Quality Engineering Using Robust Design. Upper Saddle River, NJ: PTR Prentice-Hall.

Poulston, J., \& Yiu, A. Y. K. (2011). Profit or Principles: Why Do Restaurants Serve Organic Food? International Journal of Hospitality Management, 30, 184-191. http://dx.doi.org/10.1016/j.ijhm.2010.04.004

Raajpoot, N. A. (2002). TANGSERV: A Multiple Item Scale for Measuring Tangible Quality in Food Service Industry. Journal of Foodservice Business Research, 5, 109-127. http://dx.doi.org/10.1300/J369v05n02 08

Radman, M. (2005). Consumer Consumption and Perception of Organic Products in Croatia. British Food Journal, 107, 263273. http://dx.doi.org/10.1108/00070700510589530

Reddy, V. S., Bush, R. J., \& Roudik, R. (1995). A Market-Oriented Approach to Maximizing Product Benefits: Cases in U.S. Forest Products Industries. US Forest Service, 19-38.

Robertson, A., Tirado, C., Lobstein, T., Jermini, M., Knai, C., Jensen, J. et al. (2004). Food and Health in Europe: A New Basis for Action. European Series, No. 96. Copenhagen: WHO Regional Publications.

Ryan, M. (1999). Using Conjoint Analysis to Take Account of Patient Preferences and Go Beyond Health Outcomes: An Application to in Vitro Fertilization. Social Science and Medicine, 48, 535-546. http://dx.doi.org/10.1016/S0277-9536(98)00374-8

Ryu, K., \& Jang, S. (2008). DINESCAPE: A Scale for Customers’ Perception of Dining Environments. Journal of Foodservice Business Research, 11, 2-22. http://dx.doi.org/10.1080/15378020801926551

Schmidt, M., Affenito, S. G., Striegel-Moore, R., Khoury, P. R., Barton, B., Crawford, P. et al. (2005). Fast-Food Intake and Diet Quality in Black and White Girls: the National Heart, Lung, and Blood Institute Growth and Health Study. Archives of Pediatrics \& Adolescent Medicine, 159, 626-631. http://dx.doi.org/10.1001/archpedi.159.7.626

Soriano, D. R. (2002). Customers' Expectations Factors in Restaurants: The Situation in Spain. International Journal of Quality and Reliability Management, 19, 1055-1068. http://dx.doi.org/10.1108/02656710210438122

Stahler, C. (2009). How Many Vegetarians Are There? Vegetarian Journal, 4, 6-9.

Sulek, J. M., \& Hensley, R. L. (2004). The Relative Importance of Food, Atmosphere, and Fairness of Wait: The Case of a Full-Service Restaurant. Cornell Hotel and Restaurant Administration Quarterly, 45, 235-248.

Sun, L. H. (1995). Consumer Involvement in Restaurant Selection: A Measure of Satisfaction/Dissatisfaction (I). Journal of Nutrition in Recipe and Menu Development, 1, 45-58. http://dx.doi.org/10.1300/J071v01n02_04

Turner, M., \& Collison, R. (1988). Consumer Acceptance of Meals and Meal Components. Food Quality and Preference, 1, 21-24. http://dx.doi.org/10.1016/0950-3293(88)90004-3

U. N. Report (2010). UN Urges Global Move to Meat and Dairy-Free Diet. Lesser Consumption of Animal Products Is Necessary to Save the World from the Worst Impacts of Climate Change. http://www.guardian.co.uk/environment/2010/jun/02/un-report-meat-free-diet

U. S. Department of Health and Human Services (USDHHS) (2010). Dietary Guidelines for Americans. http://www.health.gov/dietaryguidelines/dga2010/dietaryguidelines2010.pdf

Unilever Global Company (2011). The Population for Eating out in Taiwan. http://www.unileverfoodsolutions.tw/who-we-are/news/detail-1216._quotquot_quotquot_quotquot.html

Van der Pol, M., \& Ryan, M. (1996). Using Conjoint Analysis to Establish Consumer Preferences for Fruit and Vegetables. British Food Journal, 98, 5-12. http://dx.doi.org/10.1108/00070709610150879

Vieregge, M., Scanlon, N., \& Huss, J. (2007). Marketing Locally Grown Food Products in Globally Branded Restaurants: Do Customers Care? Journal of Foodservice Business Research, 10, 67-82. http://dx.doi.org/10.1300/J369v10n02_05

Washington DC, Word Watch (2009). Livestock Emissions: Still Grossly Underestimated. November/December. http://www.worldwatch.org/node/6297

Wasserman, D., \& Stahler, C. (1998). Reader Survey Results. Vegetarian Journal, 17, 4.

WHO (2003). Definition of Health. http://www.who.int/about/definition/en/print.html

Zanoli, R., \& Naspetti, S. (2002). Consumer Motivations in the Purchase of Organic Food: A Means-End Approach. British Food Journal, 104, 643-653. http://dx.doi.org/10.1108/00070700210425930 
Scientific Research Publishing (SCIRP) is one of the largest Open Access journal publishers. It is currently publishing more than 200 open access, online, peer-reviewed journals covering a wide range of academic disciplines. SCIRP serves the worldwide academic communities and contributes to the progress and application of science with its publication.

Other selected journals from SCIRP are listed as below. Submit your manuscript to us via either submit@scirp.org or Online Submission Portal.
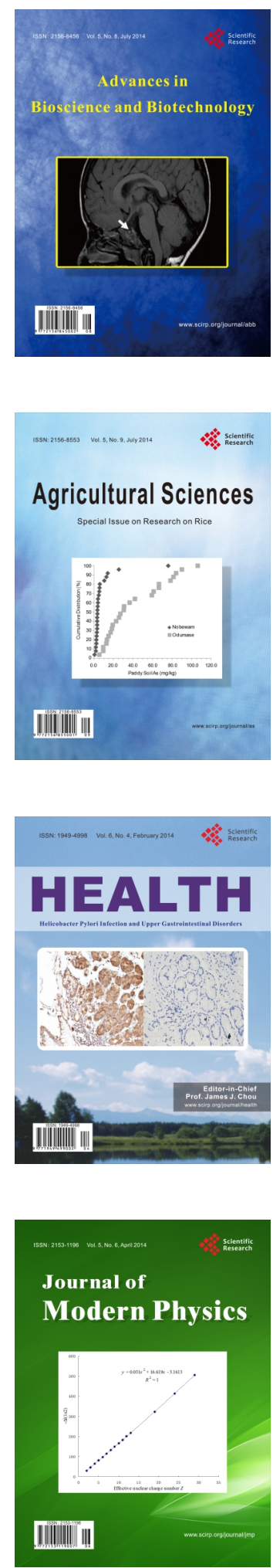
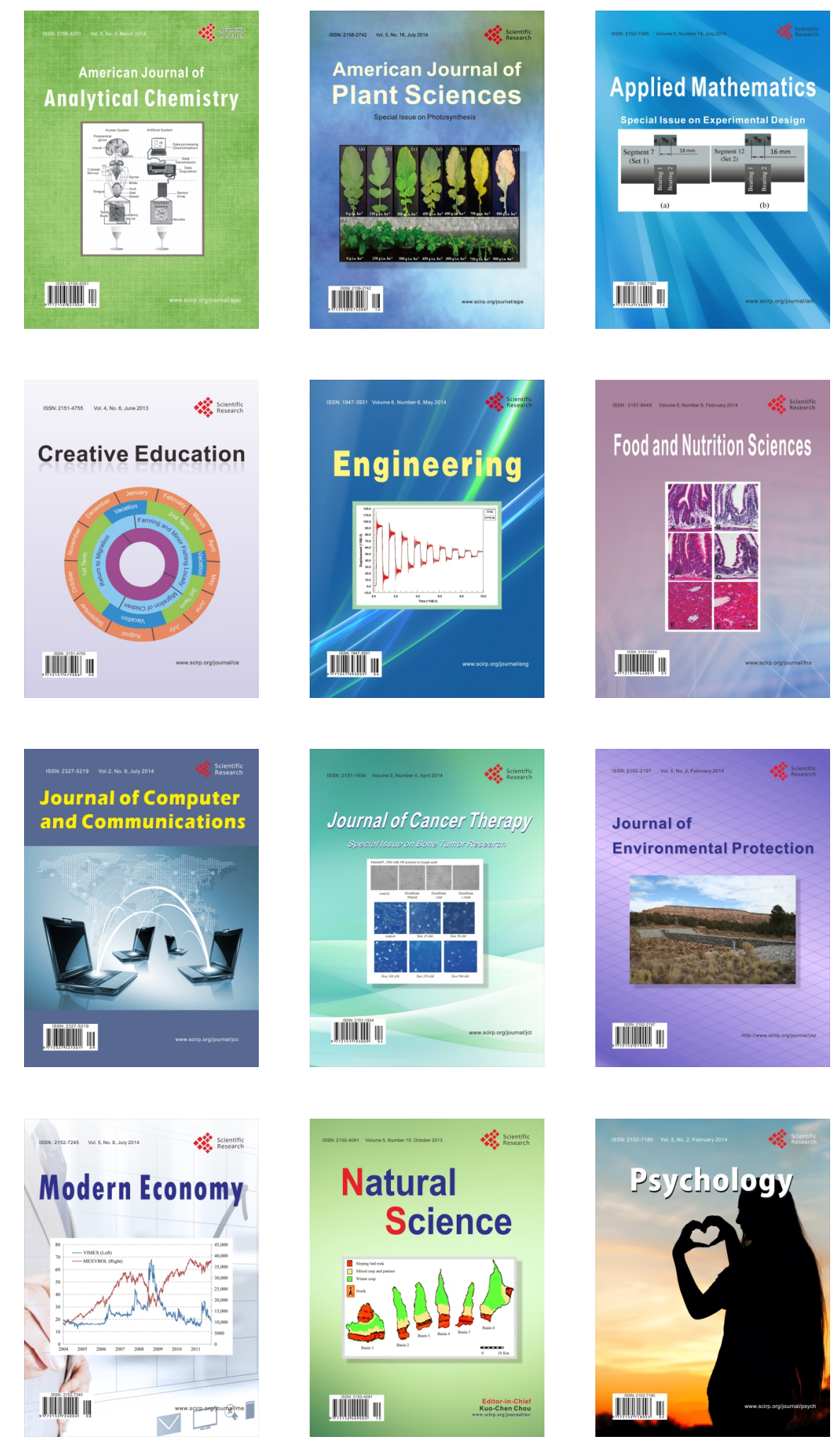